\title{
Correction to: The Hourglass Approach: Analysing Science Classroom Discursive Interactions Through Intercontextual Lens
}

\section{Luiz Gustavo Franco $^{1}$ (D) Danusa Munford ${ }^{2}$ D}

Published online: 8 November 2021

(c) Springer-Verlag GmbH Germany, part of Springer Nature 2021

\section{Correction to: Research in Science Education (2021) 51:13-33 https://doi.org/10.1007/s11165-020-09976-0}

The original version of this article unfortunately contained a mistake in the Funding section. The correct version is presented below:

Funding This study was funded by CNPq - National Council for Scientific and Technological Development - Brazil and CAPES (Coordination for the Improvement of Higher Education Personnel).

The original article has been corrected.

Publisher's Note Springer Nature remains neutral with regard to jurisdictional claims in published maps and institutional affiliations.

The original article can be found online at https://doi.org/10.1007/s11165-020-09976-0

\section{Luiz Gustavo Franco}

luizgfs@ufmg.br

1 Departamento de Métodos e Técnicas de Ensino, Universidade Federal de Minas Gerais, Belo Horizonte, Minas Gerais, Brazil

2 Centro de Ciências Naturais e Humanas, Universidade Federal do ABC, Santo André, São Paulo, Brazil 